\title{
E-Banking ICT plus Banking for Boosting Business
}

\author{
Mrs. Surekha A Sangrulkar
}

$\mathrm{PhD}$, Chhatrapati Shahu Institute of Business Education and Research, Kolhapur, Maharashtra, India

Organised By:

Management Department, Chhatrapati Shahu Institute of Business Education and Research, Kolhapur, Maharashtra

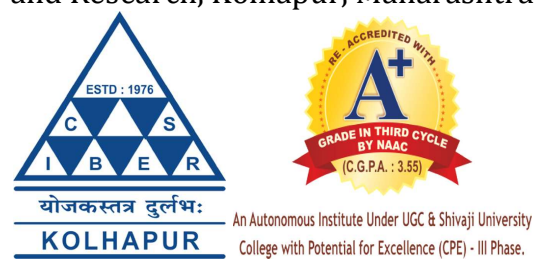

How to cite this paper: Mrs. Surekha A Sangrulkar "E-Banking- ICT Plus Banking for Boosting Business" Published in International Journal of Trend in Scientific Research and Development (ijtsrd), ISSN: 2456-6470, Special Issue | Fostering Innovation, Integration and Inclusion Through Interdisciplinary

Practices in

Management,

March 2019, pp.98-

100, URL:

https://www.ijtsrd.

com/papers/ijtsrd2

3074.pdf

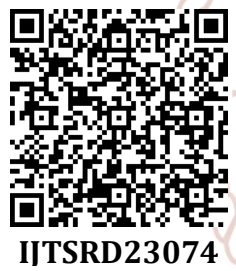

\section{INTRODUCTION}

The $21^{\text {st }}$ century will bring about an all-embracing convergence of computing, communication, information and technology. These will extremist change the way we live, work and think. Banks are investing laboriously in digital banking technology, in which customers use mobile, web or digital platforms to use banking services. Banking environment has become highly competitive today. In the changing market environment the banks will be able to survive and grow rapidly with latest technologies. In the middle of $80 \mathrm{~s}$, the various software packages for banking application in India had their beginning, when the banks started computerising the branches in limited manner. Technology has continuously playing important role in banking institutions and the services provided by them. Information technology is very helpful for product development, better market infrastructure, implementation of reliable techniques for control of risk and helps the financial intermediaries to reach geographical distant and diversified markets. Internet has significantly influenced delivery of banks. Internet has as an important medium for delivery of banking products and services. Today, information and communication technology has become the heart of banking sector, while banking industry is the heart of every economy. If it collapses so will the economy. It is absolutely evident from the current recession, in countries banks crises, and in turn. ICT has created new infrastructure for the world economy to become truly global and also provided the users of new technology a competitive advantage over their rivals.

\section{Meaning of E-Banking:}

Electronic banking is the provision of banking services through electronic and the customer can access the data without any time and geographical limitations (Sagar, 2014). E-banking provides easy access to banking services to customers. Since 1980s digitalization in communication and information technology has triggered significant social and economic changes worldwide. The internet has changed the way we communicate, the way we shop, the way we learn, the way we bank, the way we market goods, the way we buy, the way we do business, the way we store information-in short the way we live. It has become possible to exchange 
International Journal of Trend in Scientific Research and Development (IJTSRD) @ www.ijtsrd.com eISSN: 2456-6470

information instantaneously with almost e, anywhere, anytime.

The following developments in the Indian banking system have made it possible to use ICT to each banking transactions.

$>$ Automated teller machine

$>$ Electronic fund transfer

$>$ Electronic data interchange

$>$ Electronic clearing system

$>$ Debit/credit cards

$>$ Mobile banking

$>$ Internet banking

$>$ Telephone banking

The internet is the largest and cheapest technology introduced in banking industry. Progressive development in the field of ICT has brought in remarkable changes in the products as well as methods of payment and settlement system in the banking sector, in India various types payments system are functioning apart from the traditional payment system where the instruments are physically exchanged and settled manually. Smart cards are new forms of retail payment instruments, installed to facilitate retail transactions through electronic means.

\section{ICT in banking sector:}

Technological advances have eliminated time-consuming repetitive tasks, reducing human errors and broad access to banking related services. On one hand telephone banking permits to carry a non-cash transaction which was earlier not possible without a personal visit to banks. On a person to person basis technology provides customer information which would otherwise too much expensive. Customers can perform their tasks at a time and in a convenient ambience which is possible with the advent of technology.

The technological evolution of the banking industry in India has been directed largely by the various committees set up by the RBI and the government of India to review the implementation of technological change.

\section{Benefits of using ICT in Banking Sector:}

Information technology has helped to bring together both the business world and our society in general. Many fields have been impeached by information technology including but not limited to: education, healthy, entertainment, and communication. More technology will emerge as the world develops, and this technology will have both a positive and a negative impact. Information and communication technology has played a significant role in banking sector over the years. In fact ICT has made the banking industry more competitive. ICT allows the banks to cater to the needs of customers by strengthening their internal control system which are then backed by effective communication mechanisms. Widespread use of ATM, internet banking, phone banking, $24 / 7$ service, plus the ability to offer an expanded portfolio of product and services have enabled banks to improve their service to customers. ATM was one of the first significant improvements in technology as they gave banking customers greater access to their cash. Now they no longer had to queue up in banks to obtain their money. Arise of internet and phone banking, wallets have made banking even more convenient. Customers can check their balance and pay bills online without having to leave the comfort of their own home.

\section{Theoretical background}

Apparently examine the impact of ICT on banks' performance and customer service delivery, the researcher exploded various articles, journals, relevant literature and existing practice of electronic banking. In today's business, competition globalization has compelled banks to offer service 24 hours around the globe. The ICT is likely to reduce the operational cost of the banks for instance IT facilitates and speed bank procedure to accomplish standardised and low value added transactions, increase market share, and increase the revenue and profits. ICT has completely reshaping the landscape of banking industries.

\section{Impact of ICT on E-Banking:}

$>$ Reduction in cyber attracts and e-crimes

$>$ Automated payments

$>$ Issue of automated receipts

$>$ Automated contacts

$>$ Time and cost savings

$>$ Tracking of payments and expenditure

$>$ Increase in transparency

$>$ Frauds and crime prevention

$>$ Improves securities

\section{Impact of ICT on business:}

The rise of information technology has covered the way for various innovations. With the digitization of information, more and more businesses are increasingly leveraging the benefits digital tools to improve their prospects. ICT has dramatically transformed the lives of individuals. It provides the businesses the scope to analyze data and plan business strategies accordingly. ICT has had a major impact on various aspects of business.

$>$ Cloud computing

$>$ Automation of business processes

$>$ Working remotely

Mobile technology

$>$ Protecting information

$>$ Providing customer satisfaction

$>$ Management of resources

$>$ Open source software

\section{Reasons for growth of E-Banking usage}

$>$ Very convenient, comfortable and easy way to do whatever monetary transactions you wish to do with your banks

$>$ Provides 24/7 services as the e-bank never closes and has no cut-off time

$>$ Speed and easiness of conducting the digital transactions compared to paper-based dealings with walk in customers

$>$ Allows customers to be alerted via emails and phone of updates and change in their banking dealings

\section{Review of literature:}

Shirley j. Ho and K. Mallick (2006) in their study on the impact of ICT on the banking industry empirically analysed how the IT related spending can effect banks. The study examined differential effects of the IT in moderating the relationship between costs and revenue and concluded that the IT may reduce cost and may have positive effect on 
market but increased spending on IT may also lower banks profits.

Raghavan (2006) opined that present, over $85 \%$ of the finished payment transactions are electronic and traditional way of doing banking at the branch level has relatively little importance to electronic banking users.

Ashrafi and Murtaza (2008), reveals that lack of necessary ICT skills, high costs of ICT solutions and implementations and lack of availability of relevant information about suitable ICT technologies and ; lack of mechanism to find and receive advice and support at their disposal about suitable and effective technologies were some of the major barriers in adopting ICT.

Avasthi and Sharma (2000) conduct a study on "Information Technology in Banking: challenges for regulators" and discussed that the advances in technology are set to change the face of banking business. ICT has transformed both the products offered and the delivery channels used by banks in retail banking. It also greatly impacted the wholesale markets of banks.

Saha (2003) examine the booming credit card business of India attempted a thorough credit card business, a commercial bank product is one of the most profit giving sector all commercial banks.

Suresh (2008) finds that the recently developed e-banking technology created unpredicted opportunities for the banks in the way they organise financial product development, delivery and marketing via the internet. banks" pointed out that in the ever increasing intense competition, providing services quality in vital for banks to complete. The objectives of this paper are to investigate the level of service quality of private banks from the customer's perspective.

\section{Conclusion}

Firstly, there is positive impact of ICT on banking sector secondly the adoption of ICT has some business environment, social, economic and financial implications. Banks and other business organisations should indemnify efforts towards the development of ICT to reap the numerous benefits associated there in. Services provided by banks should ensure high quality services while minimize the adverse business implications of ICT.

\section{References}

[1] "Internet banking in India-challenges and opportunities" by R. K Uppal and Rimpi kaur ISBN

[2] E-banking service quality, E-customer satisfaction, and e-loyalty: by Sathyavany, N, and shrinay.

[3] "E-banking: evolution, status and prospects" by Abdul Hannan mia vol.35 No.1

[4] The Impact of ICT on banks' performance and customers service delivery in the banking industry" by Alhaji Abubakar Aliyu, Rosmaini Bin HJ Tasmin Vol-2 March 2012

[5] Www. Wikipedia.com

[6] E-banking in Rural Area- Recent Trend and Development by Jiaqin yang

[7] Websites: www.shodhganga.inflibnet.ac.in

Lee and Kim(2004) shows that the cost for using ICT, lack of suitable ICT solutions, technological knowledge of employees and their management capabilities, security concerns, outsourcing element buyer technological awareness and perceived benefits are highly related to new ICT adoptions.

Copyright (C) 2019 by author(s) and International Journal of Trend in Scientific Research and Development

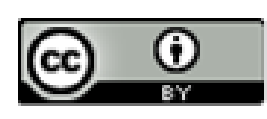
Journal. This is an Open Access article distributed under the terms of the Creative Commons Attribution License (CC BY 4.0) (http://creativecommons.org/licenses/by/4.0)

Singh and khurana(2011) in their article titles," Analysis of service Quality gap and customers satisfaction in private 